\title{
What Do Indigenous Education Policy Frameworks Reveal About Commitments to Reconciliation in Canadian School Systems?
}

Terry Wotherspoon

University of Saskatchewan, terry.wotherspoon@usask.ca

Emily Milne

MacEwan University, milnee4@macewan.ca 


\title{
What Do Indigenous Education Policy Frameworks Reveal About Commitments to Reconciliation in Canadian School Systems?
}

\begin{abstract}
The national Truth and Reconciliation Commission of Canada has challenged governments and school boards across Canada to acknowledge and address the damaging legacies of residential schooling while ensuring that all students gain an adequate understanding of relations between Indigenous Peoples and non-Indigenous peoples. This article explores the dynamics and prospects for effective change associated with reforms in elementary and secondary education systems since the release of the Commission's Calls to Action, focusing on the policy frameworks employed by provincial and territorial governments to guide these actions. The analysis examines critically the overt and hidden messages conveyed through discourses within policy documents and statements. The key questions we address include: What do current education policy frameworks and actions regarding Indigenous Peoples reveal about government approaches to education and settler-Indigenous relationships in Canada? To what extent is effective reconciliation possible, and how can it be accomplished in the context of institutional structures and discourses within a White settler colonial society? The findings reveal that substantial movement towards greater acknowledgement of Indigenous knowledge systems and incorporation of Indigenous content continues to be subordinated to or embedded within Western assumptions, norms, and standards.
\end{abstract}

Keywords

education policy, Indigenous education, reconciliation, Truth and Reconciliation Commission of Canada

\section{Creative Commons License (c) (1) (9)}

This work is licensed under a Creative Commons Attribution-Noncommercial-No Derivative Works 4.0License. 


\section{What Do Indigenous Education Policy Frameworks Reveal About Commitments to Reconciliation in Canadian School Systems?}

The question of how to achieve meaningful reconciliation between Indigenous Peoples and nonIndigenous peoples in Canada has emerged as a major national priority since the 2015 release of the Truth and Reconciliation Commission (TRC) of Canada final report. Through the TRC's (2015a) comprehensive Calls to Action, the report outlines a vision for a positive way forward that acknowledges and addresses the damaging legacy in which policies and practices associated with residential schooling have suppressed Indigenous cultures and destroyed family and community connections for several generations. The report places schools and educational activities at the heart of processes to advance reconciliation (TRC, 2015c). This article aims to critically examine reconciliation-related educational policies and practices that are oriented to ensure all students have an adequate understanding of residential schools, treaties, the historical and contemporary contributions of Indigenous Peoples to Canada, and the relationships supported through this knowledge.

In this article, we present our findings from the first stage of a larger research project on schooling and reconciliation, focusing here on a critical discourse analysis of policy frameworks and documents related to elementary and secondary schooling in provincial and territorial jurisdictions across Canada. We highlight the core policies and official statements related to Indigenous learning and reconciliation in each jurisdiction before exploring their alignment with the Education for Reconciliation Calls to Action put forward in the TRC final report. Our discussion is framed by two broad questions: What do current education policy frameworks and actions reveal about government approaches to education related to Indigenous Peoples and relationships between Indigenous Peoples and settlers in the Canadian context? To what extent is effective reconciliation possible and how can it be accomplished in the context of institutional structures and discourses framed within the context of a White settler colonial society? By exploring these questions, we seek to understand the extent to which these initiatives may or may not represent a matter of performativity and good faith rather than a movement towards foundational change.

Many relevant initiatives began to emerge in the late $20^{\text {th }}$ and early $21^{\text {st }}$ centuries, including advocacy and position papers advanced by Indigenous organizations, government agencies, and other organizations. However, the TRC Calls to Action have fostered a sense of urgency to undertake more comprehensive reform frameworks. In response, new policies and initiatives to support Indigenous students and advance reconciliation objectives have proliferated rapidly across educational levels and jurisdictions. Our analysis does not claim to cover all such policies, due to ongoing developments. Nonetheless, at this stage, no other documentation or analysis of Indigenous education initiatives exists in the literature.

\section{Literature Review}

Education lies at the heart of the TRC mandate, which calls for action to advance reconciliation, especially by supporting Indigenous students' success and fostering among all students an understanding of and respect for Indigenous Peoples and their experiences and perspectives (TRC, $2015 b$ ). These principles reinforce international recognition of Indigenous rights and knowledge as expressed in the United Nations Declaration on the Rights of Indigenous Peoples (United Nations, 
2008) and other global frameworks that affirm Indigenous rights, self-determination, and Indigenous knowledge (Battiste \& Henderson, 2008).

Educational jurisdictions across Canada have acted promptly to express formal commitment to these mandates, supported by numerous measures dedicated to improving educational outcomes for Indigenous learners and incorporating culturally relevant curriculum and programming into educational practices, in many cases building upon existing policy frameworks and reform initiatives (e.g., British Columbia Ministry of Education, n.d.b; KAIROS Canada, 2015, 2018; Ontario Ministry of Education, 2007). Recent actions suggest a significant shift in momentum and focus to achieve stated objectives. However, the TRC underscores concerns that several decades of previous calls by Indigenous organizations for effective educational change have yielded limited progress (Assembly of First Nations [AFN], 1988, 2013; National Indian Brotherhood [NIB] \& AFN, 1972; Royal Commission on Aboriginal Peoples [RCAP], 1996). The TRC (2015c) call to "eliminate" educational achievement gaps between Indigenous Peoples and non-Indigenous peoples echoes an extensive body of previous scholarship and policy statements in Canada and other White settler colonial nations (see also Gordon \& White, 2014; Hogarth, 2018; Mahuika, Berryman, \& Bishop, 2011). The TRC observed several damaging legacies of residential schooling that continue to destabilize many Indigenous people and their communities. The intergenerational impact of the residential schools is represented in such phenomena as high rates of family violence, addictions, physical and mental health issues, child custody in foster care, adult incarceration, learning problems, and low educational attainment (TRC, 2015b), all of which warrant immediate as well as longer term action. However, the Commission also emphasized the dual significance of contemporary education as a means to ensure that all Canadians understand the history and legacy of residential schooling and to ensure that Indigenous and non-Indigenous students alike are provided the tools for meaningful social and economic participation (TRC, 2015c). As time elapses, it is important to monitor progress towards achievement of these aims; in this case, by understanding the extent to which frameworks for reconciliation implemented in response to these Calls to Action are reflected in educational practices.

An extensive range of research and policy literature documents educational disparities between Indigenous Peoples and non-Indigenous peoples in Canada (Gordon \& White, 2014; Statistics Canada, 2013, Wilson \& Macdonald, 2010) to the extent that the need for educational improvement signifies a "national priority" (Council of Ministers of Education Canada, 2015, p. 3) and "great social policy challenge facing Canada" (Richards, 2008, p. i) that must be met through effective responses to a broader national "crisis" (Anaya, 2014). The literature cites several factors that contribute to these observed differences in educational outcomes and performance, including school-related dimensions (such as curriculum, instructional approaches, student support, and student-teacher relationships), community contexts, and school-community relations (Council of Ministers of Education Canada, 2010), as well as socioeconomic conditions underlying structural and institutional conditions (Gerber, 2014; Mendelson, 2006). These factors, along with racism and disconnection between official school processes and Indigenous perspectives (Bougie, Kelly-Scott, \& Arriagada, 2013; Riley \& Ungerleider, 2012; Sfeir, 2016; St. Denis, 2010), typically intersect with and reinforce one another (Bruce, Marline, \& Raham, 2012).

The Calls to Action highlight the importance of integrating Indigenous content and perspectives within curricula, in part to address widely held concerns among Indigenous students that they do not see 
themselves or their heritage adequately reflected in schools, teacher-training programs, and other educational sites (AFN, 2011; Cajete, 2000; Kim, 2015). The Calls to Action also signify the importance of further strengthening educational success and school-community relations by ensuring that programs address these concerns in a manner that is accurate, respectful, and culturally affirming (Battiste, 2013; Goulet \& McLeod, 2002; Tupper, 2014). Orientations that acknowledge the contributions and capabilities of Indigenous Peoples and their perspectives are essential in advancing beyond the limits of a deficit approach, narrowly focused on bridging gaps, which can perpetuate problems that educational reforms are seeking to address (Battiste, 2013; Fayden, 2005; Gebhard, 2017; Munroe, Borden, Orr, Toney, \& Meader, 2013). The Calls reinforce an affirmative approach that acknowledges and builds on the capabilities of Indigenous students and communities, substantiated with holistic orientations to Indigenous knowledge and cultural perspectives that are not simply add-ons to existing curricula (Battiste \& Henderson, 2009).

As progress is made to address these concerns, several obstacles remain. Educators committed to changing pedagogical practices and incorporating curricular content that acknowledges Indigenous cultural heritage and learning contexts often lack the knowledge, confidence, or support to do so effectively (Canadian Teachers' Federation [CTF], 2015; Milne, 2017; People for Education, 2017; Wotherspoon, 2006, 2008). An Ontario study revealed that educators sometimes have limited knowledge about official Indigenous curricular policy documents and directives, while others have difficulty finding, interpreting, and using resources to the extent that non-Indigenous students sometimes "go through their entire educational career without learning about Indigenous Peoples and the history and legacy of residential schooling in Canada" (Milne, 2017, p. 10). These issues reinforce the common observation in social and educational policy literature that the rhetoric and realities associated with education policy and reform are frequently misaligned (Labaree, 2010; Pak Tee, 2008). While the discussion in this article focuses on policy frameworks rather than implementation, the analysis is oriented in part to the degree of specificity, guidance, and support contained within policy directives and guidelines, which may influence the extent to which effective actions may or may not be constructed.

Our analysis also recognizes that reconciliation itself is a contested concept. For some teachers and community members, relatively modest reforms such as the addition of cultural awareness and Indigenous voices to the curriculum may be sufficient or even too much. Literature on colonization and Indigenous-settler relations, by contrast, highlights the deep challenges associated with the transformative significance of reconciliation. There is an inherently contradictory nature to settler colonial societies insofar as they bear foundations of colonization that cannot disappear entirely without the disappearance of either the colonizer or the colonized and the land-based rights to which they are entitled (Bell, 2014; Veracini, 2015; Wolfe, 2006). Colonization is embedded within relationships that are unsettling, reinforced by deep forms of violence that must be clearly acknowledged, understood, and reconciled. Without this recognition and accountability for what it draws attention to, some scholars warn that reconciliation advances the way towards extinguishment of Indigenous rights and status (Alfred, 2009; Chrisjohn \& Wasacase, 2009; Tuck \& Yang, 2012; Turner, 2013). Others, while acknowledging some potential within a settler colonial framework for coexistence among Indigenous and Western structures and epistemologies, nonetheless emphasize that reconciliation is not possible without parallel measures to ensure that Canada's institutional structures, social relationships, and discursive practices undergo some fundamental transformations (Henderson, 2013). In the context of a 
nation established by White settlers through colonial relations with Indigenous Peoples, who have constitutionally protected legal rights and status, reconciliation involves contradictions that will continue to play themselves out over an extended period of time (Bell, 2014; Veracini, 2015; Wolfe, 2006). Informed by these debates, the current analysis includes a critical assessment of how reconciliation is defined and acted upon in policy directives and guidelines issued by major educational jurisdictions.

\section{Theoretical Framework}

This research is informed by an integrative framework, particularly influenced by Bourdieu (1998; Bourdieu \& Passeron, 1979), that situates practices and strategies undertaken by social actors within a political economic orientation in relation to social structures and institutional relationships. In this framework, educational reform oriented to reconciliation occurs within the field (or social space) of schooling, which in turn intersects with other important fields including those of policy and the economy. Participants in those fields have particular resources, or forms of capital, that have specific importance within each field and are part of the relationships or positioning of actors in relation to one another. In the case of education, significant forms of capital include cultural capital (forms of knowledge and understandings associated with education that can be converted into credentials and opportunities beyond schooling), economic capital (financial assets), and social capital (networks of relationships). Reconciliation processes involve, in part, efforts to reshape the kinds of cultural capital that matter by recognizing and according significance to Indigenous cultures, histories, and perspectives. Labaree's (2010) model of school organization-highlighting intersections across levels of organization from the broader social context, rhetoric (influenced by policy makers and educational leaders), formal structures (policies, initiatives), community and neighbourhood, parent perceptions, teaching practices (perceptions, uptake), and student classroom learning - is instructive in framing key elements to be taken into consideration with respect to the analysis of educational policies. Also important is the cultivation of understandings about the impact of residential schooling and other aspects of colonization on Indigenous experiences, as well as the ways in which broader Canadian history and perspectives have been configured by these relationships.

To highlight the significance of relationships between settler colonialism and Indigenous Peoples and perspectives that are the focus of reconciliation processes, the current analysis is further informed by what Go (2016) describes as a "postcolonial-perspectival realist" approach. This orientation, influenced by postcolonial analysis and feminist standpoint theory, begins by acknowledging that our social positions or location in social space influence (but do not determine) how we understand the world (Go, 2016). An adequate scientific understanding builds from these multiple partial perspectives to construct a more comprehensive view of significant social phenomena. This analysis, complementary to that of Bourdieu, is relational in nature, augmented by recognition that social science perspectives grounded in Western epistemological traditions are themselves products of colonial relationships (Connell, 2014). To appreciate what is meant by reconciliation and explore possibilities associated with its achievement, it is necessary to identify various perspectives associated with these objectives while remaining sensitive to how colonization has shaped experiences and knowledge for dominant groups as well as for the colonized and other subaltern groups (Bhambra, 2014). Adherence to democratic principles that assert we are all equal or that the law treats all individuals the same, for instance, can obscure the realities that have made some people more vulnerable through dispossession from land, 
family, or community supports. In what Henry and Tator (2010) refer to as "democratic racism," formal recognition of democratic rights such as legal protections against discrimination coexist with practices and discourses that maintain systemic barriers against racialized minorities. These relationships can be reconceptualized as "democratic colonialism" in the case of relationships between Indigenous Peoples, the Canadian State, and non-Indigenous people insofar as formal recognition accorded Indigenous rights and status may be undermined by attitudes, actions, or policies that ignore or misrepresent those rights (Wotherspoon, 2014). Perceptions that Indigenous Peoples should not have any entitlements, protections, or forms of curricular recognition that other Canadians do not have, for instance, may be based on interpretations of Indigenous rights as "special" rights.

Our analysis seeks to highlight the ways in which educational jurisdictions across Canada have interpreted and articulated education for reconciliation within policy and practice. Under Canada's federal system of government, education is an area of provincial and territorial jurisdiction (except for education in First Nations communities, which is regulated by the federal government). Despite some convergence across the 10 provinces and three territories, significant variations are evident in some educational policies and practices (Wallner, 2014). The literature demonstrates that, despite broad support for such policies, this diversity is evident with respect to perspectives and positions regarding the meaning and practices associated with reconciliation. We are especially interested in exploring the impact that these configurations of meanings and positions may have on education policies.

\section{Methods}

Data for this article are drawn from a review of educational policies and initiatives across Canada, conducted as part of a broader program of research that explores the ways in which diverse educational participants are reforming education to support reconciliation. Findings are based on an interjurisdictional scan of statements, principles, and guidelines outlined in provincial and territorial ministries of education websites and public documents. The documents covered in the analysis are cited in the Appendix.

An initial search of provincial and territorial ministry websites and education databases (e.g., ERIC), augmented by broader Google and web searches, was conducted using key terms to locate policy statements and relevant documents. The authors and a research assistant followed up with emails and calls to ministry offices and education departments in Canada in order to clarify and confirm information. The analysis is conducted at three levels. First, policies and statements are summarized on a general thematic basis to identify commonalties and to compare and contrast the statements. We read through the policy statements (e.g., policy vision, principals, and goals) and used an inductive approach to identify themes and patterns. Second, content analysis is employed to determine the extent to which specific elements of organizational and curricular mandates appear in each context and identify specific features in the policy statements that align with the TRC (2015a) Calls to Action that may or may not be present within each thematic area.

Finally, we employ discourse analysis in order to develop a deeper understanding of the themes and messages conveyed in the policy frameworks and statements. Several previous studies have demonstrated that discourse analysis and critical discourse analysis can be effective tools for the analysis of educational practices and policies (Lester, Lochmiller, \& Gabriel, 2016, 2017; Liasidou, 2008; Rogers 
et al., 2016; Taylor, 2004). Discourse analysis, according to van Dijk (1993), seeks to understand "the role of discourse in the (re)production and challenge of dominance [italics in original]" in order to draw out the deeper meanings and relationships represented in the policy statements (p. 283). Our analysis highlights key words and phrases employed in the policy statements in relation to the context in which they are presented, with reference to particular actors or groups, mandated activities, and objectives. Within the documents or statements under review, statements that signify particular activities, power relations, and other core relationships are identified and categorized in accordance with specified organizational principles (such as statements that convey directives, such as "the teacher should..." or "parents are responsible for ...," that signify hierarchical relationships directed from educational centres; those that are focused on addressing "gaps" or deficits; or others framed in such terms as "shared responsibility" or "mutual collaboration"). The authors independently read all policy statements to identify keywords, phrases, and context, and compared notes and findings to ensure agreement. We summarize below the main foci and themes covered in the policy statements and related guidelines in relation to four categories prior to consideration of what these signify in relation to reconciliation objectives and orientations.

\section{Findings}

\section{Formal Commitments to Reconciliation}

All jurisdictions across Canada have expressed commitments or initiated actions related to reconciliation since the release of the TRC report. Six provinces (British Columbia, Alberta, Saskatchewan, Manitoba, Ontario, and New Brunswick) and all three territories produced official statements identifying commitments to reconciliation, expressing the expectation of a renewed relationship with Indigenous Peoples and a desire to move forward with the TRC (2015a) Calls to Action. Education ministries in seven jurisdictions have specific branches or units dedicated to Indigenous education ${ }^{1}$ - Alberta (First Nations, Métis, and Inuit Education Directorate), British Columbia (Aboriginal Education Branch), Manitoba (Indigenous Inclusion Directorate), Ontario (Indigenous Education Office), Nova Scotia (Mi'kmaq Services), New Brunswick (Office of First Nations Education Branch), and Northwest Territories (Indigenous Languages and Education Secretariat). Six jurisdictions (British Columbia, Alberta, Saskatchewan, Manitoba, Ontario, and Nova Scotia) maintain web pages dedicated to Indigenous education information and resources, ${ }^{2}$ and each of these jurisdictions, along with New Brunswick and Northwest Territories, have a senior-level position in government dedicated to Indigenous content in education in accordance with the TRC (2015a) Calls to Action (Call 62.iv). ${ }^{3}$ This broad policy landscape - provincial and territorial government commitments to reconciliation accompanied by a more mixed set of institutional and organizational responses-is also

\footnotetext{
${ }^{1}$ Government of British Columbia, n.d.; personal communication, Ted Cadwallader, July 13, 2018; Government of Manitoba, n.d.b; Government of New Brunswick, n.d.; Government of Northwest Territories, n.d.; personal communication, Wyatt White, July 30, 2018; and personal communication, Taunya Paquette, August 3, 2018.

${ }^{2}$ Alberta (Alberta Education, n.d.), British Columbia (Government of British Columbia, n.d.), Manitoba (Manitoba Education and Training, n.d.), Nova Scotia (Nova Scotia Aboriginal Affairs, n.d.), Ontario (Ontario Ministry of Education, n.d.), and Saskatchewan (Government of Saskatchewan, n.d.).

${ }^{3}$ Government of Alberta (2018a); personal communication, Ted Cadwallader, July 13, 2018; personal communication, Helen Robinson-Settee, July 31, 2018; personal communication, Kim Skilliter, July 12, 2018; personal communication, Mira Dunn, July 17, 2018; personal communication, Wyatt White, July 30, 2018; personal communication, Taunya Paquette, August 3, 2018; and personal communication, Rob Currie, July 27, 2018.
} 
characteristic of the more specific dimensions within the policy frameworks, though in an even more fragmented manner.

\section{Policies and Official Statements}

All provinces and territories have identified commitments and goals to improve education and cultural recognition for Indigenous Peoples, but these vary considerably in vision, scope, and detail. ${ }^{4}$ Most predate the TRC (2015a) Calls for Action, though in some cases, notably Saskatchewan and Manitoba, earlier policy frameworks have been replaced in response to the TRC. For several years, Nunavut has had the most comprehensive approach, guided by Inuit Qaujimajatuqangit knowledge and worldviews embedded within a broader orientation to self-determination (Nunavut Department of Education, 2007). Three provinces-Alberta (Alberta Learning, 2002), Ontario (Ontario Ministry of Education, 2007), and Saskatchewan (Saskatchewan Ministry of Education, 2018) — have adopted integrated guiding formal policy frameworks dedicated to Indigenous education, and strategic actions in Manitoba follow a comprehensive draft policy (Manitoba Education and Advanced Learning, 2016). All three territorial jurisdictions have introduced action plans to guide progress towards the achievement of Indigenous education priorities: Northwest Territories (Northwest Territories Education, Culture and Employment, 2011); Nunavut Department of Education (2007); and Yukon (Government of Yukon, 2014). In the Northwest Territories, a more recent document titled Education Renewal and Innovation Framework: Directions for Change (Northwest Territories Education, Culture and Employment, 2013) is oriented to improve the education system for all students. Although Indigenous Peoples and their voices, languages, and cultures are integrated throughout the document, its focus is not Indigenous education by name or purpose, so we do not include it in the analysis below. British Columbia has introduced Aboriginal Education Enhancement Agreements (AEEA) to facilitate cooperation between individual school districts, local Indigenous communities and organizations, and the Ministry of Education (British Columbia Ministry of Education, n.d.a; White, Budai, Mathew, Deighan, \& Hartej, 2012). While these frameworks have contributed to some observed improvements in academic success, trust, cultural alliances, and collective responsibility (Kitchenham, Fraser, Pidgeon, \& Ragoonaden, 2016), many school districts have not yet negotiated AEEAs. ${ }^{5}$ Five jurisdictions-New Brunswick, Newfoundland and Labrador, Nova Scotia, Prince Edward Island, and Quebec-have in place specific curricular initiatives, programs, or organizational structures dedicated to Indigenous students and cultures, but these exist separately from general education policies and frameworks to support all students.

The following section considers policy and official statements on Indigenous education across Canada with reference to the seven jurisdictions with comprehensive Indigenous education frameworksOntario, Manitoba, Saskatchewan, Alberta, Northwest Territories, Nunavut, and Yukon. We begin by exploring the messages and relationships conveyed through four themes represented in the policies in relation to purpose, voice, knowledge and worldview, and teaching, learning and assessment.

\footnotetext{
${ }^{4}$ This article focuses specifically on official Indigenous education policy statements and does not include analysis of the many education resources and support documents published by Canadian and international jurisdictions.

${ }^{5}$ There is no current count of how many British Columbia school districts have AEEAs in place (personal communication, Ted Cadwallader, July 12, 2018).
} 


\section{Purpose}

In this section, we explore the stated purpose or rationale for each document, taking into consideration the drivers or modes of legitimation employed in order to justify the need for the policy as well as the motivations outlined for stakeholders to implement the policy or statement. The analysis also focuses on the ways in which the statements are framed with respect to representative voices or sources of authority and intended audiences.

While the specific focal points and details contained in these frameworks vary considerably across jurisdictions, several notable elements stand out. The policies highlight an orientation to long-term development, whether in the form of lifelong learning (Alberta, Ontario, Yukon), early childhood foundations (Northwest Territories, Yukon), or capacity for socioeconomic contributions (Manitoba, Northwest Territories, Ontario, Yukon). In several instances, the vision statements and related objectives refer to the achievement of equitable educational opportunities and outcomes for Indigenous youth relative to other learners (Nunavut, Saskatchewan), sometimes posed as deficit reduction or elimination of gaps (Ontario, Northwest Territories). In most cases, voices that privilege the dominant state and education system perspectives are prevalent in the language and priorities conveyed in the statements.

However, two frameworks stand out from the others with respect to the integration of Indigenous worldviews and perspectives into the education system. In Saskatchewan (the only jurisdiction by the end of 2018 to have introduced a new plan in response to the Calls for Action), there is explicit reference to the "foundational" placement of Indigenous knowledge systems, cultures, and languages throughout the entire kindergarten to Grade 12 education system. Nunavut's policy is framed through a 2007 document, Inuit Qaujimajatuqangit Education Framework, named to recognize Inuit perspectives and worldviews, which inform the foundations of teaching, learning, and curriculum in the Nunavut education system. The focus of the latter is the achievement of self-reliance and individual success "guided by Inuit cultures and values" (Nunavut Department of Education, 2007, p. 7). These two examples demonstrate that, at least with regard to the general framing of educational policy, it is possible to embrace educational orientations to reconciliation in which Indigenous perspectives are deeply embedded within educational organizations and practices rather than simply added on. Draft frameworks in other jurisdictions, notably Manitoba, promise further movement in this direction.

Nonetheless, there are reasons to question how much progress has been made in these regards. The strong focus on long-term development, while important for all education systems, does not speak directly to key dimensions of reconciliation except for occasional references to Indigenous culture and residential schools, and it does not acknowledge and address factors that represent and may continue to serve as barriers to such development for Indigenous children and youth. For instance, the current Alberta Policy Framework (Alberta Learning, 2002), which is a revised version of the 1987 framework, suggests that the "urgency" of priorities to increase the educational success of Indigenous Peoples remains a longstanding but unfulfilled objective. Many of the plans identify general outcomes or individualized performance targets such as standardized test score results (Alberta Learning, 2002) or gaps in academic achievement (Government of Yukon, 2014), literacy and numeracy, and graduation rates (Ontario Ministry of Education, 2007), which stand in marked contrast to more holistic Indigenous conceptions of learning and success (Bouvier, 2010). In one case (the Northwest 
Territories), the framework document employs the word "gap" 21 times, reinforcing the supremacy of Western models of education success oriented to measurable performance standards. These relationships are explored further in the next section by focusing on how the policy statements represent and position key educational participants in relation both to one another and to other potential audiences.

\section{Voice and Audience}

All of the Indigenous education policy statements speak directly and indirectly to particular intended audiences through voices given varying degrees of expression or privilege. This includes whether multiple perspectives including those of Indigenous Peoples and organizations are captured; the general approach to education, in terms of one-sided or shared responsibility; and who is and is not part of decision-making processes. We focus on whether there is a "problem" or "solution" identified, if a deficit approach is taken, and how and by which standards education success is framed.

The policy frameworks are oriented toward various education system participants and broader audiences. Several, including Alberta and Yukon, highlight processes of public consultation and engagement with Indigenous communities, Elders, and other representative groups that inform policy statements. In the case of Nunavut, consultations and meetings with an Elders' advisory committee and many other groups and committees spanned several years. The Nunavut document sought to capture diverse voices and contributions:

In order to establish a philosophical and foundational grounding in Inuit Qaujimajatuqangit, Curriculum School Services development work on this document began with consultation with Elders, Inuit educators and community experts. Focused discussion addressed the following questions: What's worth knowing? How should it be taught? What are the values behind what we are teaching? (Nunavut Department of Education, 2007, p. 20)

The Saskatchewan provincial framework also stresses that "First Nations and Métis education goals and outcomes are not an 'add-on' but are integral to the planning and focus of the education sector as a whole" (Government of Saskatchewan, 2018, p. 5), noting further that the "infusion of Indigenous content, perspectives and ways of knowing" in the curricula "benefit [s] all learners" (p. 2). Acknowledging that the provincial education system "is not the sole expert," the policy framework commits the ministry to consultation with key stakeholders, including Indigenous organizations, Elders, and Knowledge Keepers, for their "expert opinion when it comes to educating First Nation students" (Government of Saskatchewan, 2018, p. 3).

The Ontario First Nation, Métis and Inuit Education Policy Framework (Ontario Ministry of Education, 2007), by contrast, speaks mostly to educators, school boards, and ministry officials. The framework document does not provide details about how the policy came to be or what, if any, consultation was done with Elders, Indigenous educators and organizations, or local Indigenous communities. The document does express a desire to increase involvement of and collaboration with Indigenous parents, communities, and educational authorities at the Ministry, school board, and school level but does not elaborate on how this would be accomplished. Although, at one point in the policy, it is stated that the framework is intended to aid education stakeholders "to help" Indigenous students "achieve their [emphasis added] education goals," success seems to be framed in the document around 
“achieving the ministry's goals [emphasis added] for improving education outcomes of First Nation, Métis, and Inuit students" (Ontario Ministry of Education, 2007, p. 9). By privileging official aims over goals set by Indigenous Peoples and students themselves (which may be framed through alternative conceptions of success), the policy has potential to undermine rather than enhance orientations to education consistent with processes of reconciliation. The contrasting approaches conveyed in the diverse framework documents point to the varied ways in which different types of knowledge, perspectives, and ways of knowing are positioned in educational policies.

\section{Knowledges and Worldviews}

Across jurisdictions, Indigenous education policy frameworks recognize the importance of including Indigenous knowledges and perspectives in schooling practices and curriculum. However, with a few exceptions, educational practices that build on Indigenous cultural knowledge and orientations continue to be overwhelmed by content, individualized orientations to learning and outcomes, and measurable attributes grounded in Western knowledge and perspectives. Indigenous perspectives are more often presented as means to achieve official state ends than as crucial features of a fully rounded educational experience. The Alberta policy framework, for example, advances goals that are intended to "support" Indigenous students and "not intended to diminish or detract from the importance of their strong value systems, cultures, languages and communities," with a specified objective to "strengthen the use, sharing, recognition and value of Indigenous knowledge and language” (Alberta Learning, 2002, p. 11). Ontario's Indigenous education policy framework speaks to the importance of supporting Indigenous students while also enhancing knowledge and understanding of Indigenous cultures and histories among all students and education stakeholders. While the Ontario document acknowledges Indigenous worldviews and ways of knowing through passing references to Indigenous perspectives, it provides little sense of whether or how these might be integrated into the total school experience.

Some jurisdictions do appear poised to integrate Indigenous perspectives more fully into educational practice. Saskatchewan's framework stresses the importance of validating and drawing on Indigenous knowledge, acknowledging from the start "First Nations and Métis worldviews as valid ways of knowing and understanding the world" (Government of Saskatchewan, 2018, p. i). This commitment is supported by objectives to ensure that all students will be able to gain knowledge and understanding of Indigenous worldviews through the "infusion" of Indigenous perspectives and ways of knowing in provincial curricula (Government of Saskatchewan, 2018). The Yukon action plan (Government of Yukon, 2014) seeks to balance its focus on mainstream success with learning models based on "traditional knowledge, cultural practices, histories and languages," which are oriented to "knowing the traditional cultural way of life" (pp. 5-6). Similarly, Manitoba's draft First Nations, Métis, and Inuit Education Policy Framework (Manitoba Education and Advanced Learning, 2016) identifies "criteria for ensuring that the curriculum reflects the perspectives of First Nation, Métis, and Inuit peoples" along with other knowledge and skills to ensure that Indigenous students are equipped "to walk in both western and Indigenous ways of life" (p. 6). The Northwest Territories framework also focuses on curricular aims that enable Indigenous Peoples to develop the capacity to live in "two worlds," combining a strong sense of identity and ability to navigate the Western world with skills and knowledge to continue Indigenous languages and traditions (Northwest Territories Education, Culture and Employment, 2011). The document cites in several places the importance of including Indigenous languages and cultures in education programs, citing the need to revise the kindergarten to Grade 12 
curriculum to include "literacy competencies and life skills reflective of northern worldviews and citizenship" (Northwest Territories Education, Culture and Employment, 2011, p. 30). However, the policy statement does not address the place of Indigenous knowledge and, as in most other jurisdictions, Indigenous education policy is oriented more to Indigenous learners than to students in general.

The Nunavut education framework is more comprehensive, embedding Indigenous voices and philosophies not as a specific Indigenous educational initiative, but at the core of its overall education policy framework. Inuit perspectives and ways of knowing and doing inform every page of the 62-page policy document, speaking to the core of the curriculum, as well as learning and assessment approaches, grounded in continual acknowledgement that "Inuit beliefs, laws, principles and values are the foundation of education in Nunavut"(Nunavut Department of Education, 2007, p. 56). Inuit Peoples appear to have been consulted and involved in all aspects of creating this document, which recognizes Elders, families, youth, schools, and community learning centres collectively as sources of knowledge (Nunavut Department of Education, 2007, p. 17).

The education frameworks, collectively, demonstrate some movement toward incorporation of Indigenous knowledge, perspectives, and orientations into learning. The extent to which these commitments can be sustained or realized remains uncertain. Knowledge about Indigenous cultures, languages, and experiences is a specific form of cultural capital that many teachers have not yet developed the capacity and confidence to draw upon. Moreover, some educators regard the incorporation of Indigenous content into classroom teaching and learning as optional, on the periphery of mandated curriculum, or segregated and sometimes exotic content (Milne, 2017; Schaefli, Godlewska, \& Rose, 2018; St. Denis, 2010). Prospects to integrate Indigenous content and learning orientations into the curriculum are also jeopardized by offsetting demands to prioritize learning outcomes oriented to individualization, globalization, multiculturalism, and market competitiveness (Bouvier, 2010; St. Denis, 2011). These patterns are also evident in the policy objectives related to teaching, learning, and student assessment.

\section{Teaching, Learning, and Assessment}

All of the policy frameworks draw attention to the need to incorporate Indigenous content and culturally appropriate curricula, pedagogical approaches, and services to support student success. Several common themes appear across frameworks, though there are significant variations in the depth to which these commitments are acknowledged and outlined. Broad support for teaching Indigenous languages is represented as central to policy frameworks in the northern territories and Saskatchewan, whereas it is framed more narrowly in other cases, including the Mi'kmaq-specific policy in Nova Scotia. Saskatchewan's policy statement repeatedly asserts the importance of implementing "culturally responsive and affirming curricula, relevant instruction and assessment" (Government of Saskatchewan, 2018 , p. 6). This theme is echoed in other frameworks to highlight the need to build capacity around understanding and employing teaching methods and assessment tools that reflect Indigenous learning styles and cultural perspectives (Ontario Ministry of Education, 2007); the principle of culturally respectful, sensitive, "learner-centred and equity focused" educational activities (Alberta Learning, 2002, p. 14); and orientations to teaching and curricular content that reflect "culture-based education" teaching approaches and curricular content (Northwest Territories Education, Culture and Employment, 2011, pp. 18, 29-30). 
Another common feature within the Indigenous education frameworks is the identification of benchmarks or indices of success. Some of these, informed at least in part through consultation with Indigenous educators and community members, incorporate holistic and relational conceptions of success. The Nunavut framework refers to a process of "dynamic assessment" informed by Inuit philosophies but also "linked closely" to achievement outcomes:

This [assessment] process must involve students and parents in both setting goals and in assessing progress towards meeting those goals throughout the student's learning path. At the completion of each learning stage, there is a set of task-based benchmarks that will help track student progress in relation to others and to set common standards for all students in Nunavut schools. (Nunavut Department of Education, 2007, p. 53)

Other plans also refer to success in terms of relationships (between students and teachers, schools and communities, and Indigenous and non-Indigenous participants) and Indigenous principles (such as the holistic "cycle of lifelong learning" conceptual framework underlying Saskatchewan's plan). However, parallel to the broader aims conveyed through many of the policy frameworks, learning-specific outcomes are also commonly presented with reference to measurable individual outcomes defined in accordance with education system norms and expectations, rather than with reference to holistic development and Indigenous conceptions of learning success. Saskatchewan's framework, which otherwise reflects adherence to the Calls to Action, targets specific benchmarks defined by Western standards including aims to reduce the gap in graduation rates by 50 percent and have "eighty percent of students ... at grade level or above in reading, writing and math” by 2020 (Government of Saskatchewan, 2018, p. 18). In some cases, even objectives associated with knowledge about Indigenous Peoples and cultures are quantified, as illustrated with Alberta performance measures determined in accordance with the "percentage of learners with knowledge and understanding of First Nations, Métis, and Inuit cultures as identified through provincial Grades 3, 6, and 9 Achievement Tests and Diploma Examinations" (Alberta Learning, 2002, p. 24).

Commitments to integrate Indigenous content and adopt pedagogical strategies to engage Indigenous students more fully stand as the most consistent and visible features of policy reform frameworks across jurisdictions. As observed in the next section, they are in most cases supported by initiatives consistent with the advancement of educational objectives outlined in the TRC Calls to Action. What remains uncertain is the extent to which such measures may gain traction or effectiveness in education systems confronted with guidelines and expectations that are not always consistent with, and sometimes stand in tension with, priorities associated with reconciliation.

\section{Alignment with Education for Reconciliation Calls to Action}

This section considers the alignment between provincial and territorial efforts and Education for Reconciliation Calls to Action put forward in the TRC (2015a) report. A summary is first provided of the alignment between the policy statements examined above and the Education for Reconciliation Calls to Action (Table 1), supplemented by discussion of additional materials beyond the official policy statements to provide a snapshot of where Canadian jurisdictions are at in terms of movement towards the Education for Reconciliation Calls to Action. 


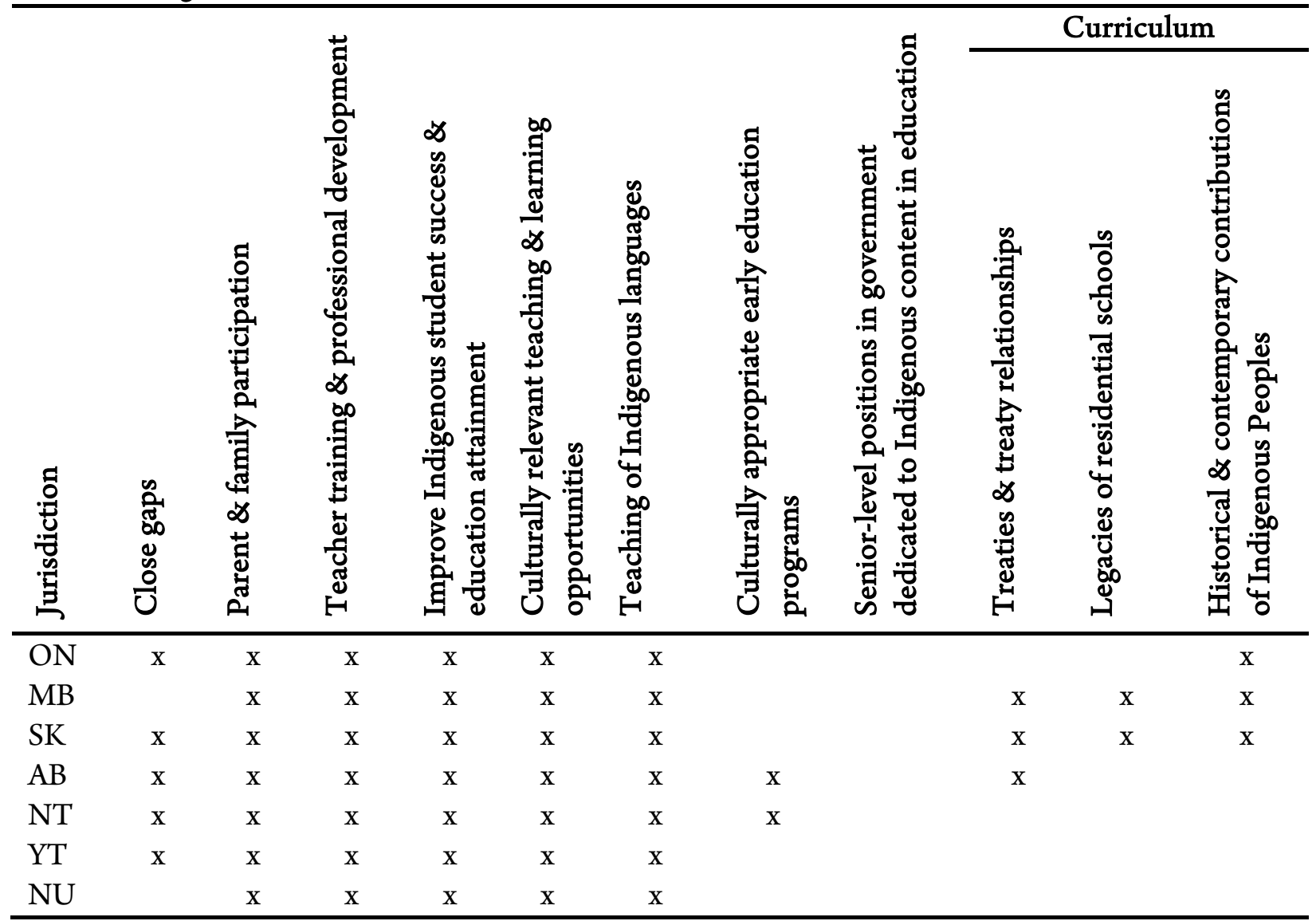

Note. $\mathrm{ON}=$ Ontario, $\mathrm{MB}=$ Manitoba, $\mathrm{SK}=$ Saskatchewan, $\mathrm{AB}=$ Alberta, $\mathrm{NT}=$ Northwest Territories, $\mathrm{YT}=\mathrm{Yukon}, \mathrm{NU}=$ Nunavut.

Most of the policy statements were produced before the release of the TRC Report in 2015, with the exception of the Saskatchewan and draft Manitoba policy documents, which speak directly to TRC Calls to Action. As a result, the existing policy statements may not reflect fully other provincial and territorial efforts introduced to align with the TRC's Education for Reconciliation Calls to Action. Therefore, our analysis of the extent to which progress is being made to align education systems with Calls to Action associated with education draws from personal communication, media releases, news stories, and information provided on provincial and territorial websites as well as from the policy framework statements.

\section{Curriculum}

The TRC (2015a) has called upon education systems to take several actions to implement curriculum and educational practices that acknowledge and address the legacies of residential schools, honour and advance understanding of treaties and treaty relationships, preserve and revitalize Indigenous languages and cultures, and educate students about the historical and contemporary contributions of Indigenous Peoples (Calls 13-14 and 62-63). Jurisdictions to varying extents have taken steps to include Indigenous content in the curriculum. Two territories-Nunavut and Yukon - have integrated Indigenous content throughout all subject areas and grade levels. In the Northwest Territories, Indigenous content is 
mandatory in the social studies curriculum from kindergarten to Grade12 and a northern studies course is required for graduation, supported by two curriculum documents, the Dene Kede (Northwest Territories Education, Culture and Employment, 1993) and Inuuqatigiit (Northwest Territories Education, Culture and Employment, 1996), to provide cultural and linguistic guidance for educators as they integrate Indigenous content into classroom instruction. Alberta, British Columbia, Manitoba, Newfoundland and Labrador, Saskatchewan, and Ontario have mandatory Indigenous content integrated into social studies curricula throughout grade levels. Nova Scotia has mandatory Indigenous content integrated into social studies in several grades as well as in a course on citizenship and Canadian history. In Prince Edward Island, Indigenous content is integrated into Grade 9 social studies. No evidence was found of mandatory content in New Brunswick and Quebec curricula. Several jurisdictions also have optional course offerings, including Blackfoot language, Cree language, and Mi'kmaw studies courses (Alberta, Nova Scotia) and Native studies or Aboriginal studies courses (Alberta, Manitoba, Ontario). Anti-racism is cited as an important dimension of many of the curricular initiatives, but Manitoba addresses the phenomenon most directly by outlining measures to support anti-racist education.

Several documents (those for Ontario, Manitoba, Saskatchewan, Alberta, Yukon, Northwest Territories, Nunuavut) acknowledge the importance of Indigenous rights as recognized in constitutional and inherent rights, land claims, treaties, and Indigenous Peoples' authority, control, and responsibility over education. The policy frameworks stress that knowledge, learning, and preservation of Indigenous cultures and languages are important; in many cases, framing education as a mechanism or vehicle for preserving culture and language. However, they are less likely to speak directly to concepts of worldviews, perspectives, ways of knowing, or Indigenous knowledge. The term "worldview" is used throughout the Saskatchewan and draft Manitoba documents; twice in the Nunavut document; once in the Northwest Territories, Ontario, Alberta; and it is not mentioned in the Yukon document. Similarly, reference to "ways of knowing" appears throughout the Saskatchewan document and once in the Manitoba and Nunavut documents, and is absent from the Ontario, Northwest Territories, Alberta, and Yukon frameworks. The Saskatchewan, Manitoba, Ontario, and Nunavut documents highlight in several places the distinctiveness of Indigenous "perspectives," which are also acknowledged in a single entry in each of the Alberta and Yukon documents, but not in the Northwest Territories. The notion of "excelling in both worlds" is discussed in the Manitoba, Yukon, and Northwest Territories policy documents, and referenced in a side quote in the Alberta document.

These uneven responses are reflected in a report card produced by KAIROS Canada (2018) to assess progress in relation to the level of public commitment to and implementation of actions to advance reconciliation in each province and territory. With respect to public commitment, four jurisdictions received a grade of "excellent," including Alberta, Manitoba, Northwest Territories, and Ontario. Eight jurisdictions (British Columbia, New Brunswick, Newfoundland, Nova Scotia, Nunavut, Prince Edward, Saskatchewan, and Yukon) received a grade of "good," and one jurisdiction, Quebec, received an assessment of "needs improvement." With respect to implementation, only one jurisdiction (Manitoba) received a grade of "excellent" while 10 (Newfoundland, Prince Edward Island, Nova Scotia, Ontario, Saskatchewan, Alberta, British Columbia, Northwest Territories, Yukon, and Nunavut) were assessed as "good," one (New Brunswick) was rated "needs improvement", and one (Quebec) was assessed as having "significant work required." 


\section{Teacher Training and Standards}

The Calls to Action speak explicitly to teacher training and professional development (TRC, 2015a, Call 63 iv) to advance reconciliation. Three jurisdictions have teacher quality standards or teaching standards in place for current teachers related to learning about Indigenous Peoples through teaching certification or professional development required for teaching. Alberta announced plans in 2018 to implement appropriate quality standards for new teachers and superintendent leadership that would apply to all educators and administrators in the province's education system beginning in September 2019 (Government of Alberta, 2018b, 2018c, 2018d). These standards include requirements related to understanding Indigenous worldviews, beliefs, and values and applying foundational knowledge about Indigenous Peoples in classroom learning. In the Northwest Territories, new teachers' teaching certificates are good for two years in which time they complete 50 hours of professional development. After this period, they are eligible for another certificate, valid for five years during which they undertake another 50 hours of professional development. The professional development changes according to needs but there is always an Indigenous learning component embedded within the training (personal communication, Simon LePage, July 9, 2018).The Northwest Territories has also required educators since the 2010-2011 school year to dedicate a minimum of two full days of on-the-land culturally appropriate orientation for their teaching and school administrative staff (Northwest Territories Education, Culture, and Employment, 2011). In the Yukon, Cultural Inclusion Standards require all school staff and school councils to participate in mandatory cultural awareness training through Yukon College and a mandatory annual orientation by the local First Nation (Yukon Government, 2016; personal communication, Joy Dornian, July 9, 2018).

With regard to pre-service training, we identified through email communication and searches of program calendars requirements for students to complete an Indigenous focused course or learning requirement before graduation in 34 out of the 51 Canadian faculties or colleges of education. Many of these, such as requirements for a single course in Indigenous studies over a four-year degree program, are relatively loose. Only two jurisdictions so far-Manitoba and Ontario-require teachers applying for certification to have mandatory training in Indigenous learning or relevant knowledge, though these are paralleled tacitly in many other jurisdictions through the teacher training program requirements. In Manitoba, requirements for the Permanent Professional Teaching Certificate include the need for " 3 credit hours of Aboriginal Issues coursework” (Government of Manitoba, n.d.a, Certificates table, Academic Requirements and Permanent Professional Teaching Certificate cell; see also The Education Administration Act, 2016). Meanwhile, Ontario does not have mandatory Indigenous issues courses, but Regulation 347/02 of the Accreditation of Teacher Education Programs specifies that teacher education programs must include content about Indigenous histories, cultures, perspectives, and contributions (Ontario College of Teachers, 2017).

As in many other areas, some progress is being made towards ensuring that teachers are well equipped to understand Indigenous Peoples and act in ways that advance reconciliation. However, much ground remains to be made up, especially given the prominence within the literature of concerns that teachers often lack the knowledge and confidence to address important issues related to Indigenous cultures and rights and Indigenous-settler relations (Canadian Teachers' Federation, 2015; Milne, 2017; People for Education, 2017; Wotherspoon, 2006, 2008). 


\section{Concluding Observations}

Our analysis of policy frameworks and related guidelines reveals considerable movement towards greater incorporation of Indigenous content in both school curricula and teacher education across the country. However, there is also tremendous variation in the depth and intensity of these developments, raising questions about whether commitments to reconciliation can be realized in many contexts. While our focus in this article has been limited to provincial and territorial policy documents, it is likely that an examination of implementation and pedagogical practice would reveal even further nuances (see for example Gebhard, 2017). To a large extent, the policy documents and statements represent a kind of public performance-idealized broad statements and wish lists with little specification of roles and responsibilities and few concrete statements on tasks and timeframes. The implementation of initiatives in response to the TRC Calls to Action across provincial and territorial jurisdictions in Canada is a large task involving coordination among several large, diverse, and complex organizations. Efforts to date appear to be somewhat piecemeal with little concerted centralized efforts or communication at the national (see for example Government of Canada, 2018), provincial and territorial, or local levels.

Further research is needed to examine current understandings and perceptions of education for reconciliation among teachers and school staff who are interpreting and implementing policy directives on the ground. What impact do the emerging reconciliation-related policies and initiatives have on teacher practice and classroom learning? To what extent are these initiatives a matter of performativity and good faith as opposed to a movement towards foundational change?

The evidence to date suggests that formal commitments to reconciliation and related curricular and pedagogical actions are notable steps forward in addressing damaging colonial legacies of schooling. However, they are not in themselves guarantees that schools across Canada will become spaces in which Indigenous Peoples and their voices and experiences are affirmed and advanced. The current policy frameworks, with a few exceptions, continue to position Indigenous Peoples as the "other," who are now being repositioned to fill historical curricular voids. The plans are mostly silent on fundamental questions about what reconciliation really represents and what models of schooling and educational practice would be necessary in order to advance these meaningful forms of reconciliation. While some of the reform commitments present opportunities to include more Indigenous content in the existing curriculum and within the existing curriculum boundaries, they do not call into question the dominant structures and practices, including those represented by schooling itself, that in many respects continue to suppress many opportunities to fulfill the social and educational aspirations of Indigenous students.

If progress is going to be made towards reconciliation, stakeholders at all levels of the education system need to put words into action. One Indigenous educator explained to us that she does not support education for reconciliation-related policies and provincial or territorial statements of commitment, such as those identified above, because they seem politically motivated and are not sincere. Beyond words, she is waiting for action to demonstrate a real commitment. Another educator who works at a high school that serves a predominantly Indigenous student population shared the saying with us that "weighing a pig doesn't make it fatter." This means, in part, that the propensity to focus on evaluating Indigenous students by Western education measures will not address issues of educational disparities (Richards \& Mahboubi, 2018). It also means that educational policies must be guided by, and contribute to, continuing critical reflection among educational participants and scholars on the meaning 
of reconciliation and how reconciliation, in turn, may be limited by a failure to place a focus on decolonization at the core of educational practice. Effective educational reform requires attention to the broader context, including the political and economic characteristics of the regional and jurisdictional sites in which school systems operate as well as the deeper working of settler colonial relations. McGregor's (2013) observation with respect to schooling in Nunavut also has much wider significance:

The process of decolonizing schools is not achieved solely through the integration of Indigenous content, but through examining the power relationships that determine questions (and answers) regarding school structures, policy and decision-making, curriculum and pedagogy, teacherstudent-community relationships, access to and assessment of student success. (p. 107)

Aside from some acknowledgement of Indigenous epistemological and pedagogical orientations, actions to advance reconciliation through education continue to be dominated by Western approaches to knowledge and practice, reinforced especially through methods of teaching and assessment reflecting a colonial education system. While Canadian educators are encouraged to incorporate Indigenous content and perspectives into classroom learning this objective is likely to be contradicted by pedagogical methods and learning objectives grounded in Western assumptions and practices without parallel consideration of more fundamental transformations that might be required to mobilize effective reform.

\section{References}

Alberta Education. (n.d.). First Nations, Métis and Inuit education: Indigenous education. Retrieved from https://education.alberta.ca/first-nations-métis-and-inuit-education/indigenouseducation/

Alberta Learning. (2002). First Nations, Métis, and Inuit Education Policy Framework. Retrieved from https://education.alberta.ca/media/482255/first-nations-m\%C3\%A9tis-and-inuit-policyframework-2002.pdf

Alfred, T. (2009). Restitution is the real pathway to justice for Indigenous Peoples. In G. Younging, J. Dewar, \& M. DeGagné (Eds.), Response, responsibility, and renewal: Canada's truth and reconciliation journey (pp. 179-187). Ottawa, ON: Aboriginal Healing Foundation.

Anaya, J. (2014). The situation of Indigenous Peoples in Canada. Report of the Special Rapporteur on the Rights of Indigenous Peoples, addendum (A/HRC/27/52/Add.2). Geneva: Office of the High Commissioner for Human Rights. Retrieved from http://unsr.jamesanaya.org/docs/ countries/2014-report-canada-a-hrc-27-52-add-2-en.pdf

Assembly of First Nations (AFN). (1988). Tradition and education: Towards a vision of our future. $A$ declaration of First Nations jurisdiction over education. Ottawa, ON: Assembly of First Nations.

Assembly of First Nations (AFN).(2011). Virtual summit, AFN Survey of First Nation Post-Secondary Students 2011. Ottawa, Canada: Author. 
Assembly of First Nations (AFN). (2013). Assembly of First Nations Special Chiefs Assembly concludes, reaffirmed resolve for First Nations control of First Nations education [Press release]. Retrieved from http://www.afn.ca/en/news-media/latestnews/assembly-of-firstnations-special-chiefs-assembly-concludes-reaffirmed

Battiste, M. (2013). Decolonizing education. Saskatoon, Canada: Purich.

Battiste, M., \& Henderson, J. Y. (2009). Naturalizing Indigenous knowledge in Eurocentric education. Canadian Journal of Native Education, 32(1), 5-18.

Bell, A. (2014). Relating Indigenous and settler identities: Beyond domination. New York, USA: Palgrave. doi: https://doi.org/10.1057/9781137313560

Bhambra, G. K. (2014). Connected sociologies. London, England: Bloomsbury.

Bougie, E., Kelly-Scott, K., \& Arriagada, P. (2013). The education and employment experiences of First Nations people living off reserve, Inuit, and Métis: Selected findings from the 2012 Aboriginal Peoples Survey (Catalogue no. 89-653-X). Ottawa, ON: Statistics Canada. Retrieved from http://www.statcan.gc.ca/pub/89-653-x/89-653-x2013001-eng.pdf

Bourdieu, P. (1998). Practical reason: On the theory of action. Stanford, USA: Stanford University Press.

Bourdieu, P., \& Passeron, J. C. (1979). The inheritors: French students and their relation to culture. Chicago, USA: University of Chicago Press.

Bouvier, R. (2010). Aboriginal education and assessing students' ways of knowing: Standardized tests vs. multiple ways of knowing. Our Schools, Our Selves, 20(1), 103-117.

British Columbia Ministry of Education. (n.d.a). Aboriginal Enhancement Agreements. Victoria, Canada: Government of British Columbia. Retrieved from https://www2.gov.bc.ca/gov/ content/education-training/k-12/administration/program-management/ aboriginal-education/aboriginal-education-enhancement-agreements

British Columbia Ministry of Education. (n.d.b.). Ministry of Education report on actions taken to support Truth and Reconciliation Commission of Canada's Calls to Action. Victoria, Canada: Government of British Columbia. Retrieved from https://www2.gov.bc.ca/gov/content/ education-training/k-12/aboriginal-education/actions-taken-on-reconciliation

Bruce, D., Marlin, A., \& Raham, H. (2012). Literature review on factors affecting the transition of Aboriginal youth from school to work. Ottawa, Canada: Council of Ministers of Education Canada.

Cajete, G. (2000). Native science: Natural laws of interdependence. Santa Fe, USA: Clear Light.

Canadian Teachers' Federation (CTF). (2015). CTF survey on teachers' perspectives on Aboriginal education in public schools in Canada: Summary report. Status of Aboriginal education in your 
school/curriculum. Retrieved from https://www.ctf-fce.ca/Research-Library/CTF-SurveyTeachers-Perspectives-on-Aboriginal-Education-Summary-Report-web.pdf

Chrisjohn, R., \& Wasacase, T. (2009). Half-truths and whole lies: Rhetoric in the 'apology' and the Truth and Reconciliation Commission. In G. Younging, J. Dewar, \& M. DeGagné (Eds.), Response, responsibility, and renewal: Canada's truth and reconciliation journey (pp. 217-229). Ottawa, Canada: Aboriginal Healing Foundation.

Connell, R. (2014). Using southern theory: Decolonizing social thought in theory, research and application. Planning Theory, 13(2), 201-223. doi: https://doi.org/10.1177/ $\underline{1473095213499216}$

Council of Ministers of Education Canada (CMEC). (2010). Strengthening Aboriginal success: Moving toward Learn Canada 2020: CMEC Summit on Aboriginal Education Summary report. Toronto, Canada: Council of Ministers of Education Canada.

Council of Ministers of Education Canada (CMEC). (2015). CMEC Aboriginal educators'symposium: Summary report. Retrieved from https://www.cmec.ca/Publications/Lists/ Publications/Attachments/359/CMEC-Aboriginal-Educators-Symposium-2015-EN.pdf

The Education Administration Act, C.C.S.M. 2015, c. E10 (2015). Retrieved from https://web2.gov.mb.ca/laws/regs/current/_pdf-regs.php?reg=115/2015

Fayden, T. (2005). How children learn: Getting beyond the deficit myth. New York, USA: Routledge. doi: https://doi.org/10.4324/9781315634111

Gebhard, A. (2017). Reconciliation or racialization? Contemporary discourses about residential schools in the Canadian Prairies. Canadian Journal of Education, 4O(1), 1-30.

Gerber, L. (2014). Education, employment, and income polarization among Aboriginal men and women in Canada. Canadian Ethnic Studies, 46(1), 121-144. doi: https://doi.org/ $\underline{10.1353 / \text { ces. } 2014.0015}$

Go, J. (2016). Postcolonial thought and social theory. New York, USA: Oxford University Press. doi: https://doi.org/10.1093/acprof:oso/9780190625139.001.0001

Gordon, C. E., \& White, J. P. (2014). Indigenous educational attainment in Canada. The International Indigenous Policy Journal, 5(3). doi: https://doi.org/10.18584/iipj.2014.5.3.6

Goulet, L., \& McLeod, Y. (2002). Connections and reconnections: Affirming cultural identity in Aboriginal teacher education. McGill Journal of Education, 37(3), 355-369. doi: https://doi.org/10.1007/s13384-018-0277-8

Government of Alberta. (2018a). Education telephone directory. Retrieved from https://www.alberta.ca/albertaFiles/PrintableDirectories/EDUC.PDF 
Government of Alberta. (2018b). Teacher quality standards. Edmonton, Canada: Alberta Education.

Government of Alberta. (2018c). Leadership quality standards. Edmonton, Canada: Alberta Education.

Government of Alberta. (2018d). Superintendent leadership quality standards. Edmonton, Canada: Alberta Education.

Government of British Columbia. (n.d.). Aboriginal education in British Columbia. Retrieved from https://www2.gov.bc.ca/gov/content/education-training/ways-to-learn/aboriginal-education

Government of Canada. (2018). Education for reconciliation. Learn how the Government of Canada is responding to the Truth and Reconciliation Commission's Calls to Action 62 to 65. Retrieved from https://www.aadnc-aandc.gc.ca/eng/1524504501233/1524504535167

Government of Manitoba. (n.d.a). Indigenous Inclusion Directorate. Retrieved from http://www.edu.gov.mb.ca/aed/index.html

Government of Manitoba. (n.d.b). Professional certification. Retrieved from http://www.edu.gov.mb.ca/k12/profcert/certificates/iet/certificates.html

Government of New Brunswick. (n.d.). Aboriginal affairs. Retrieved from http://www2.gnb.ca/ content/gnb/en/departments/aboriginal_affairs.html

Government of Northwest Territories. (n.d.). Indigenous Languages and Education Secretariat. Retrieved from https://www.ece.gov.nt.ca/en/services/indigenous-languages-and-education$\underline{\text { secretariat }}$

Government of Saskatchewan. (n.d.). First Nations and Métis education. Retrieved from https://www.saskatchewan.ca/residents/education-and-learning/first-nations-and-metiseducation

Government of Saskatchewan. (2018). Inspiring success: First Nations and Métis Pre-K-12 Education Policy Framework. Retrieved from http://www.publications.gov.sk.ca/redirect.cfm?p= $\underline{90278 \& \mathrm{i}=107115}$

Government of Yukon. (2014). YFNJoint Education Action Plan 2014-2024: A blueprint to strengthen our roots and to close the education gap. Retrieved from https://cyfn.ca/wpcontent/uploads/2013/09/Approved-JEAP.pdf

Henderson, J. Y. (2013). Incomprehensible Canada. In J. Henderson \& P. Wakeham (Eds.), Reconciling Canada: Critical perspectives on the culture of redress (pp. 115-126). Toronto, Canada: University of Toronto Press.

Henry, F., \& Tator, C. (2010). The colour of democracy: Racism in Canadian society (4 ${ }^{\text {th }}$ ed.). Scarborough, Canada: Nelson. 
Hogarth, M. (2018). Talkin' bout a revolution: The call for transformation and reform in Indigenous education. The Australian Educational Researcher, 45(5), 663-674.

KAIROS Canada. (2015).Report card: Provincial and territorial curriculum on Indigenous Peoples. Retrieved from https://www.kairoscanada.org/what-we-do/indigenous-rights/windsofchangereport-cards

KAIROS Canada. (2018). Revised report card: Provincial and territorial curriculum on Indigenous Peoples. Retrieved from https://www.kairoscanada.org/what-we-do/indigenousrights/windsofchange-report-cards

Kim, E-J. A. (2015). Neo-colonialism in our schools: Representations of Indigenous perspectives in Ontario science curricula. McGill Journal of Education, $50(1), 1-25$.

Kitchenham, A., Fraser, T., Pidgeon, M., \& Ragoonaden, K. (2016). Aboriginal Education Enhancement Agreements: Complicated conversations as pathways to success. Victoria, Canada: BC Ministry of Education. Retrieved from http://www2.gov.bc.ca/assets/gov/education/administration/ kindergarten-to-grade-12/aboriginal-education/research/aeea_report.pdf

Labaree, D. (2010). Someone has to fail: The zero-sum game of public schooling. Cambridge, USA: Harvard University Press.

Lester, J. N., Lochmiller, C. R., \& Gabriel, R. (2016). Locating and applying critical discourse analysis within education policy: An introduction. Education Policy Analysis Archives, 24(102). doi: https://doi.org/10.14507/epaa.24.2768

Lester, J. N., Lochmiller, C. R., \& Gabriel, R. (2017). Exploring the intersection of education policy and discourse analysis: An introduction. Education Policy Analysis Archives, 25(25). doi: https://doi.org/10.14507/epaa.25.2971

Liasidou, A. (2008). Critical discourse analysis and inclusive educational policies: The power to exclude. Journal of Education Policy, 23(5), 483-500. doi: https://doi.org/10.1080/ $\underline{02680930802148933}$

Mahuika, R., Berryman, M., \& Bishop R. (2011). Issues of culture and assessment in New Zealand education pertaining to Māori students. Assessment Matters, 3, 183-198.

Manitoba Education and Advanced Learning. (2016). Draft First Nation, Métis and Inuit Education Policy Framework: Transforming educational experiences through the Five Rs: Recognition, revitalization, relevance, and relationships and reconciliation. Retrieved from https: / digitalcollection.gov.mb.ca/awweb/pdfopener?smd=1\&did=25297\&md=1

Manitoba Education and Training. (n.d.). Indigenous education. Winnipeg: Government of Manitoba. Retrieved from http://www.edu.gov.mb.ca/k12/abedu/index.html 
McGregor, H. E. (2013). Situating Nunavut education with Indigenous education in Canada. Canadian Journal of Education, 36(2), 87-118.

Mendelson, M. (2006). Aboriginal Peoples and postsecondary education in Canada. Ottawa, Canada: The Caledon Institute for Social Policy.

Milne, E. (2017). Implementing Indigenous education policy directives in Ontario public schools: Experiences, challenges and successful practices. The International Indigenous Policy Journal, $8(3)$. doi: https://doi.org/10.18584/iipj.2017.8.3.2

Munroe, E. A., Borden, L. L., Orr, A. M., Toney, D., \& Meader, J. (2013). Decolonizing Aboriginal education in the $21^{\text {st }}$ century. McGill Journal of Education, 48(2), 317-337.

doi: https://doi.org/10.7202/1020974ar

National Indian Brotherhood \& Assembly of First Nations (NIB \& AFN). (1972). Indian control of Indian education: Policy paper. Ottawa, Canada: Author.

Northwest Territories Education, Culture and Employment. (1993). Dene Kede. Education: A Dene perspective. Yellowknife, Canada: Government of Northwest Territories. Retrieved from https://www.ece.gov.nt.ca/en/services/curriculum/dene-kede-and-inuuqatigiit

Northwest Territories Education, Culture and Employment. (1996). Inuuqatigiit: The curriculum from the Inuit perspective. Yellowknife, Canada: Government of Northwest Territories. Retrieved from https://www.ece.gov.nt.ca/en/services/curriculum/dene-kede-and-inuuqatigiit

Northwest Territories Education, Culture, and Employment. (2011). Aboriginal Student Achievement Education Plan. Retrieved from https://www.ece.gov.nt.ca/sites/ece/files/resources/asa_education_plan.pdf

Nova Scotia Aboriginal Affairs. (n.d.). Education: Learning guide. Halifax, Canada: Government of Nova Scotia. Retrieved from https://novascotia.ca/abor/education/learning-guide/

Nunavut Department of Education. (2007). Inuit Qaujimajatuqangit Education Framework for Nunavut curriculum. Iqaluit, Canada: The Government of Nunavut. Retrieved from https://www.gov.nu.ca/sites/default/files/files/Inuit\%20Qaujimajatuqangit\%20ENG.pdf

Ontario College of Teachers. (2017). Accreditation resource guide. Retrieved from https://www.oct.ca//media/PDF/Accreditation\%20Resource\%20Guide/Accreditation_Reso urce Guide EN WEB.pdf

Ontario Ministry of Education. (n.d.). Indigenous education in Ontario. Toronto, Canada: Government of Ontario. Retrieved from http://www.edu.gov.on.ca/eng/aboriginal/supporting.html

Ontario Ministry of Education. (2007). Ontario First Nation, Métis and Inuit Education Policy Framework. Toronto, Canada: Queen's Printer for Ontario. Retrieved from www.edu.gov.on.ca/eng/aboriginal/fnmiFramework.pdf 
Pak Tee, N. (2008). Education policy rhetoric and reality gap: A reflection. International Journal of Educational Management, 22(6), 595-602. doi: https://doi.org/10.1108/09513540810895471

People for Education. (2017). Competing priorities (annual report on Ontario's publicly funded schools 2017). Retrieved from http://www.peopleforeducation.ca/wp-content/uploads/2017/ 06/P4E-annual-report-2017.pdf

Richards, J. (2008). Closing the Aboriginal/non-Aboriginal education gaps (C. D. Howe Institute Backgrounder, Issue 116). Toronto, Canada: C.D. Howe Institute.

Richards, J., \& Mahboubi, P. (2018). Measuring student outcomes: The case for identifying Indigenous students in Canada's PISA sample (E-Brief 272). Ottawa, Canada: C.D. Howe Institute. doi: https://doi.org/10.2139/ssrn.3124496

Riley, T., \& Ungerleider, C. (2012). Self-fulfilling prophecy: How teachers' attributions, expectations, and stereotypes influence the learning opportunities afforded Aboriginal students. Canadian Journal of Education, 35(2), 303-333.

Rogers, R., Schaenen, I., Schott, C., O’Brien, K., Trigos-Carrillo, L., Starkey, K., \& Carter Chasteen, K. (2016). Critical discourse analysis in education: A review of the literature. Review of Educational Research, 86(4), 1192 -1226. doi: https://doi.org/10.3102/0034654316628993

Royal Commission on Aboriginal Peoples (RCAP). (1996). Report of the Royal Commission on Aboriginal Peoples: Vol. 1. Looking forward, looking back. Ottawa, Canada: Minister of Supply and Services Canada.

Saskatchewan Ministry of Education. (2018). Inspiring success: First Nations and Métis Pre-K-12 Education Policy Framework. Regina, Canada: Government of Saskatchewan.

Schaefli, L. M., Godlewska, A. M. C., \& Rose, J. (2018). Coming to know Indigeneity: Epistemologies of ignorance in the 2003-2015 Ontario Canadian and world studies curriculum. Curriculum Inquiry, 48(4), 475-498. doi: https://doi.org/10.1080/03626784.2018.1518113

Sfeir, G. (2016). Bridging the gap: Towards a cosmopolitan orientation in the social studies curriculum in Saskatchewan high schools [Doctoral dissertation, University of Saskatchewan]. Retrieved from https://ecommons.usask.ca/handle/10388/7435

St. Denis, V. (2010). A study of Aboriginal teachers' professional knowledge and experience in Canadian schools. Toronto, Canada: Canadian Teachers' Federation. Retrieved from https://www.oise.utoronto.ca/otso/UserFiles/File/ABORIGINAL_Report2010_EN_Web.pdf

St. Denis, V. (2011). Silencing Aboriginal curricular content and perspectives: "There are other children here." Review of Education, Pedagogy, and Cultural Studies, 33(4), 306-317.

doi: https://doi.org/10.1080/10714413.2011.597638 
Statistics Canada. (2013). The educational attainment of Aboriginal Peoples. Canada National Household Survey (Catalogue no. 99-012-X2011003). Ottawa, Canada: Statistics Canada. Retrieved from http://www12.statcan.gc.ca/nhs-enm/2011/as-sa/99-012-x/99-012x2011003 3-eng.pdf

Taylor, S. (2004). Researching educational policy and change in 'new times': Using critical discourse analysis. Journal of Education Policy, 19(4), 433-451. doi: https://doi.org/10.1080/ $\underline{0268093042000227483}$

Truth and Reconciliation Commission of Canada (TRC). (2015a). Truth and Reconciliation Commission of Canada: Calls to Action. Retrieved from http://nctr.ca/assets/reports/ Calls to Action_English2.pdf

Truth and Reconciliation Commission of Canada (TRC). (2015b). Canada's residential schools: The legacy: Vol. 5. The final report of the Truth and Reconciliation Commission of Canada. Retrieved from trc.ca/assets/pdf/Volume 5 Legacy_English_Web.pdf

Truth and Reconciliation Commission of Canada (TRC). (2015c). Canada's residential schools: Reconciliation: Vol. 6. The final report of the Truth and Reconciliation Commission of Canada. Retrieved from http://www.trc.ca/assets/pdf/Volume_6_Reconciliation English_Web.pdf

Tuck, E., \& Yang, K. W. (2012). Decolonization is not a metaphor. Decolonization: Indigeneity, Education, and Society, 1(1), 1-40.

Tupper, J. A. (2014). The possibilities for reconciliation through difficult dialogues: Treaty education as peacebuilding. Curriculum Inquiry, 44(4), 469-488. doi: https://doi.org/10.1111/curi.12060

Turner, D. (2013). On the idea of reconciliation in contemporary Aboriginal politics. In J. Henderson, \& P. Wakeham (Eds.), Reconciling Canada: Critical perspectives on the culture of redress (pp. 100-114). Toronto, Canada: University of Toronto Press.

United Nations. (2008). Declaration on the Rights of Indigenous Peoples. Retrieved from http://www.un.org/esa/socdev/unpfii/documents/DRIPS_en.pdf

Van Dijk, T.A. (1993). Principles of critical discourse analysis. Discourse and Society, 43(2), 249-283. doi: https://doi.org/10.1177/0957926593004002006

Veracini, L. (2015). The settler colonial present. New York, USA: Palgrave Macmillan. doi: https://doi.org/10.1057/9781137372475

Wallner, J. (2014). Learning to school: Federalism and public schooling in Canada. Toronto, Canada: University of Toronto Press. doi: https://doi.org/10.3138/9781442669284 
White, K., Budai, J., Mathew, D., Deighan, M. R., \& Hartej, G. (2012). Educators' perspectives about a public school district's Aboriginal Education Enhancement Agreement in British Columbia. Canadian Journal of Native Education, 35(1), 42-60.

Wilson, D., \& Macdonald, D. (2010). The income gap between Aboriginal Peoples and the rest of Canada. Ottawa, Canada: Canadian Centre for Policy Alternatives. Retrieved from https://www.policyalternatives.ca/sites/default/files/uploads/publications/reports/docs/Abo riginal\%20Income\%20Gap.pdf

Wolfe, P. (2006). Settler colonialism and the elimination of the Native. Journal of Genocide Research, $8(4), 387-409$. doi: https://doi.org/10.1080/14623520601056240

Wotherspoon, T. (2006). Teachers' work in Canadian Aboriginal communities. Comparative Education Review, SO(4), 672-694. doi: https://doi.org/10.1086/507060

Wotherspoon, T. (2008). Teachers' work intensification and education contradictions in Aboriginal communities. Canadian Review of Sociology, 45(4), 389-418. doi: https://doi.org/10.1111/ j.1755-618X.2008.00021.x

Wotherspoon, T. (2014). Seeking reform of Indigenous education in Canada: Democratic progress or democratic colonialism? AlterNative: An International Journal of Indigenous Peoples, 10(4), 323-339. doi: https://doi.org/10.1177/117718011401000402

Yukon Government. (2016). Cultural Inclusion Standards in all schools. Whitehorse, USA: Yukon Government. Retrieved from http://www.education.gov.yk.ca/pdf/schools/Cultural Inclusion_Standards in all Schools.pdf

\section{Appendix: Government Documents and Ministerial Statements Analyzed}

\section{A1: Indigenous Policy Framework Documents}

Alberta Learning. (2002). First Nations, Métis, and Inuit Education Policy Framework. Retrieved from https://education.alberta.ca/media/482255/first-nations-m\%C3\%A9tis-and-inuit-policyframework-2002.pdf

British Columbia Ministry of Education. (n.d.). Aboriginal Enhancement Agreements. Retrieved from https://www2.gov.bc.ca/gov/content/education-training/k-12/administration/programmanagement/aboriginal-education/aboriginal-education-enhancement-agreements

Government of Saskatchewan. (2018). Inspiring success: First Nations and Métis Pre-K-12 Education Policy Framework. Retrieved from http://www.publications.gov.sk.ca/redirect.cfm? $\mathrm{p}=90278 \& \mathrm{i}=107115$ 
Government of Yukon. (2014). YFN Joint Education Action Plan 2014-2024: A blueprint to strengthen our roots and to close the education gap. Retrieved from https://cyfn.ca/wpcontent/uploads/2013/09/Approved-JEAP.pdf

Manitoba Education and Advanced Learning. (2016). Draft First Nation, Métis and Inuit Education Policy Framework: Transforming educational experiences through the Five Rs: Recognition, revitalization, relevance, and relationships and reconciliation. Retrieved from https://digitalcollection.gov.mb.ca/awweb/pdfopener?smd=1\&did=25297\&md=1

Northwest Territories Education, Culture, and Employment. (2011). Aboriginal Student Achievement Education Plan. Yellowknife: Government of Northwest Territories. Retrieved from https://www.ece.gov.nt.ca/sites/ece/files/resources/asa_ _ education_plan.pdf

Nunavut Department of Education. (2007). Inuit Qaujimajatuqangit Education Framework for Nunavut Curriculum. Iqaluit, Canada: The Government of Nunavut. Retrieved from https://www.gov.nu.ca/sites/default/files/files/Inuit\%20Qaujimajatuqangit\%20ENG.pdf

Nunavut Department of Education. (2008). Inuglugijaittuq foundation for inclusive education in Nunavut schools. Iqaluit, Canada: The Government of Nunavut. Retrieved from https://www.gov.nu.ca/sites/default/files/files/Inclusive\%20Education\%20ENG.pdf

Ontario Ministry of Education. (2007). Ontario First Nation, Métis and Inuit Education Policy Framework. Toronto, Canada: Queen's Printer for Ontario. Retrieved from www.edu.gov.on.ca/eng/aboriginal/fnmiFramework.pdf

Saskatchewan Ministry of Education. (2018). Inspiring success: First Nations and Métis Pre-K-12 Education Policy Framework. Regina, Canada: Government of Saskatchewan.

\section{A2: Statements on Reconciliation}

Alberta Government. (2014). Expression of reconciliation for the legacy of the Indian Residential School System. Edmonton, Canada: Government of Alberta. Retrieved from https://education.alberta.ca/media/563919/albertas-expression-of-reconciliation.pdf

Gallant, B. (2015). Statement on release of Truth and Reconciliation Commission Report, Premier of New Brunswick. Fredericton, Canada: Government of New Brunswick. Retrieved from http://www2.gnb.ca/content/gnb/en/news/news_release.2015.06.0532.html

Government of Northwest Territories. (2015). Meeting the challenge of reconciliation: The Government of the Northwest Territories response to the Truth and Reconciliation Commission Calls to Action. Retrieved from http://www.assembly.gov.nt.ca/tableddocuments/meeting-challenge-reconciliation-government-northwest-territories-response-truth

Government of Saskatchewan. (n.d.). Moving forward with the Truth and Reconciliation Commission. Regina: Government of Saskatchewan. Retrieved from https://www.saskatchewan.ca/ 
residents/first-nations-citizens/moving-forward-with-the-truth-and-reconciliationcommission\#

Government of Saskatchewan. (2015). Premier's statement on the Truth and Reconciliation Commission Report. Retrieved from https://www.saskatchewan.ca/government/news-andmedia/2015/june/05/commission-report

Graham, D. (2014). Ministerial statement on the Truth and Reconciliation Commission. Whitehorse, Canada: Yukon Government. Retrieved from http://www.gov.yk.ca/news/14-131.html

Notley, R. (2015). Letter to Cabinet Ministers from Premier of Alberta. Retrieved from http://indigenous.alberta.ca/documents/Premier-Notley-Letter-Cabinet-Ministers.pdf

Ontario Government. (2016). The journey together: Ontario's commitment to reconciliation with Indigenous Peoples. Toronto, Canada: Queen's Printer for Ontario. Retrieved from https://www.ontario.ca/page/journey-together-ontarios-commitment-reconciliationindigenous-peoples

The Path to Reconciliation Act, CCSM c. R90.5 (2016). Retrieved from https://web2.gov.mb.ca/bills/ 40-5/b018e.php

Taptuna, P. (2015). Premier Taptuna reacts to Truth and Reconciliation Commission's Final Report. Iqaluit, Canada: Government of Nunavut. Retrieved from https://www.gov.nu.ca/ eia/news/premier-taptuna-reacts-truth-and-reconciliation-commissions-final-report

Yukon Government. (2016). Yukon Government's Deputy Minister's report to the Premier on the Truth and Reconciliation Commission of Canada Report: "Honouring the Truth, Reconciling for the Future." Whitehorse: Yukon Government. Retrieved from http://www.eco.gov.yk.ca/ aboriginalrelations/pdf/DM-Report-Truth-and-Reconciliation-Commissions-Calls-toAction.pdf

\section{A3: Other Government and Related Documents}

Alberta Education. (n.d.). First Nations, Métis and Inuit Education: Indigenous education. Retrieved from https://education.alberta.ca/first-nations-métis-and-inuit-education/indigenouseducation/

British Columbia Ministry of Education. (n.d.a). BC K-12 school and district contact information. Victoria: Government of British Columbia. Retrieved from http://www.bced.gov.bc.ca/ apps/imcl/imclWeb/Home.do

British Columbia Ministry of Education. (n.d.b.). Ministry of Education report on actions taken to support Truth and Reconciliation Commission of Canada's Calls to Action. Victoria, Canada: Government of British Columbia. Retrieved from https://www2.gov.bc.ca/gov/content/ education-training/k-12/aboriginal-education/actions-taken-on-reconciliation 
The Education Administration Act, C.C.S.M. 2015, c. E10 (2015). Retrieved from https://web2.gov.mb.ca/laws/regs/current/_pdf-regs.php?reg=115/2015

Government of Alberta. (2018a). Education telephone directory. Edmonton, Canada: Alberta Education. Retrieved from https://www.alberta.ca/albertaFiles/PrintableDirectories/ EDUC.PDF

Government of Alberta. (2018b). Teacher quality standards. Edmonton, Canada: Alberta Education.

Government of Alberta. (2018c). Leadership quality standards. Edmonton, Canada: Alberta Education.

Government of Alberta. (2018d). Superintendent leadership quality standards. Edmonton, Canada: Alberta Education.

Government of British Columbia. (n.d.). Aboriginal education in British Columbia. Retrieved from https://www2.gov.bc.ca/gov/content/education-training/ways-to-learn/aboriginal-education

Government of British Columbia. (2016a). Métis Nation Relationship Accord II. Retrieved from https://www2.gov.bc.ca/assets/gov/british-columbians-our-governments/indigenouspeople/aboriginal-peoples-documents/metis nation_reconciliation_accord ii nov 16 2016.pdf

Government of British Columbia. (2016b). Draft joint agenda: Implementing the Commitment Document: Concrete actions: Processes, structures, and legislative and policy change. Retrieved from https://www2.gov.bc.ca/assets/gov/environment/natural-resource-stewardship/ consulting-with-first-nations/agreements/commitment_document_work_plan_2016.pdf

Government of British Columbia. (2017). Factsheet: Reconciliation at the heart of relationship with Aboriginal people. Retrieved from https://news.gov.bc.ca/factsheets/factsheet-reconciliationat-the-heart-of-relationship-with-aboriginal-peoples

Government of Canada. (2018). Education for reconciliation. Learn how the Government of Canada is responding to the Truth and Reconciliation Commission's Calls to Action 62 to 65. Retrieved from https://www.aadnc-aandc.gc.ca/eng/1524504501233/1524504535167

Government of Manitoba. (n.d.a). Indigenous Inclusion Directorate. Retrieved from http://www.edu.gov.mb.ca/aed/index.html

Government of Manitoba. (n.d.b). Professional certification. Retrieved from http://www.edu.gov.mb.ca/k12/profcert/certificates/iet/certificates.html

Government of New Brunswick. (n.d.). Aboriginal affairs. Retrieved from http://www2.gnb.ca/content/gnb/en/departments/aboriginal_affairs.html

Government of Northwest Territories. (n.d.). Indigenous Languages and Education Secretariat. Retrieved from https://www.ece.gov.nt.ca/en/services/indigenous-languages-and-education$\underline{\text { secretariat }}$ 
Government of Saskatchewan. (n.d.). First Nations and Métis education. Retrieved from https://www.saskatchewan.ca/residents/education-and-learning/first-nations-and-metiseducation

Manitoba Education and Training. (n.d.). Indigenous education. Winnipeg, Canada: Government of Manitoba. Retrieved from http://www.edu.gov.mb.ca/k12/abedu/index.html

Northwest Territories Education, Culture and Employment. (1993). Dene Kede. Education: A Dene perspective. Yellowknife, Canada: Government of Northwest Territories. Retrieved from https://www.ece.gov.nt.ca/en/services/curriculum/dene-kede-and-inuuqatigiit

Northwest Territories Education, Culture and Employment. (1996). Inuuqatigiit: The curriculum from the Inuit perspective. Yellowknife, Canada: Government of Northwest Territories. Retrieved from https://www.ece.gov.nt.ca/en/services/curriculum/dene-kede-and-inuuqatigiit

Northwest Territories Education, Culture and Employment. (2013). Education Renewal and Innovation Framework: Directions for change. Retrieved from https://www.ece.gov.nt.ca/ sites/ece/files/024-renewal_framework_en_proof_2.pdf

Nova Scotia Aboriginal Affairs. (n.d.). Education: Learning guide. Halifax, Canada: Government of Nova Scotia. Retrieved from https://novascotia.ca/abor/education/learning-guide/

Ontario College of Teachers. (2017). Accreditation resource guide. Retrieved from https://www.oct.ca//media/PDF/Accreditation\%20Resource\%20Guide/Accreditation_Reso urce_Guide_EN_WEB.pdf

Ontario Ministry of Education. (n.d.). Indigenous education in Ontario. Toronto, Canada: Government of Ontario. Retrieved from http://www.edu.gov.on.ca/eng/aboriginal/supporting.html

Yukon Government. (2016). Cultural Inclusion Standards in all schools. Retrieved from http://www.education.gov.yk.ca/pdf/schools/Cultural_Inclusion_Standards in all Schools. pdf 